
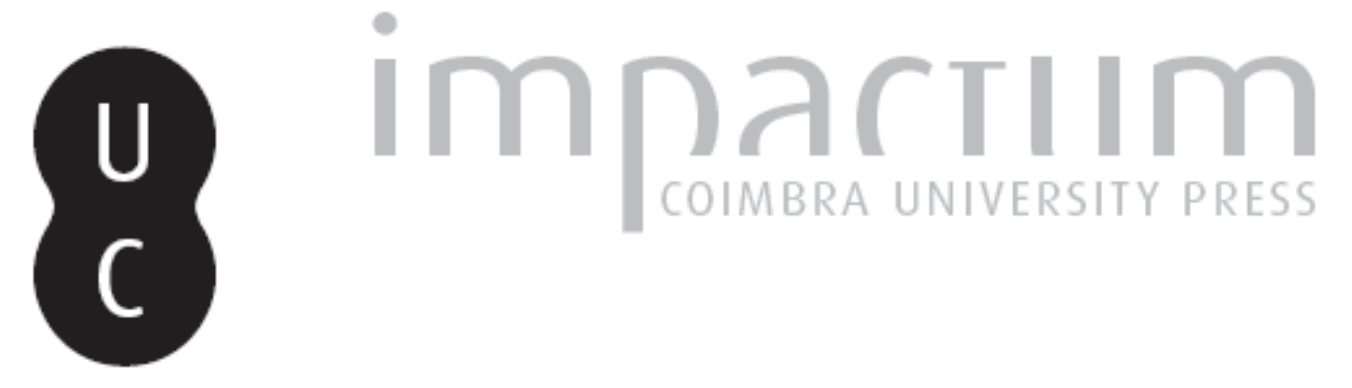

\title{
Famílias em Coimbra nos séculos XVIII e XIX
}

Autor(es): Mota, Guilhermina

Publicado por: Centro de História da Sociedade e da Cultura

URL persistente:

URI:http://hdl.handle.net/10316.2/39527

DOI:

DOI:http://dx.doi.org/10.14195/1645-2259_10-2_1

Accessed : $\quad$ 26-Apr-2023 04:12:04

A navegação consulta e descarregamento dos títulos inseridos nas Bibliotecas Digitais UC Digitalis, UC Pombalina e UC Impactum, pressupõem a aceitação plena e sem reservas dos Termos e Condições de Uso destas Bibliotecas Digitais, disponíveis em https://digitalis.uc.pt/pt-pt/termos.

Conforme exposto nos referidos Termos e Condições de Uso, o descarregamento de títulos de acesso restrito requer uma licença válida de autorização devendo o utilizador aceder ao(s) documento(s) a partir de um endereço de IP da instituição detentora da supramencionada licença.

Ao utilizador é apenas permitido o descarregamento para uso pessoal, pelo que o emprego do(s) título(s) descarregado(s) para outro fim, designadamente comercial, carece de autorização do respetivo autor ou editor da obra.

Na medida em que todas as obras da UC Digitalis se encontram protegidas pelo Código do Direito de Autor e Direitos Conexos e demais legislação aplicável, toda a cópia, parcial ou total, deste documento, nos casos em que é legalmente admitida, deverá conter ou fazer-se acompanhar por este aviso.

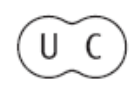




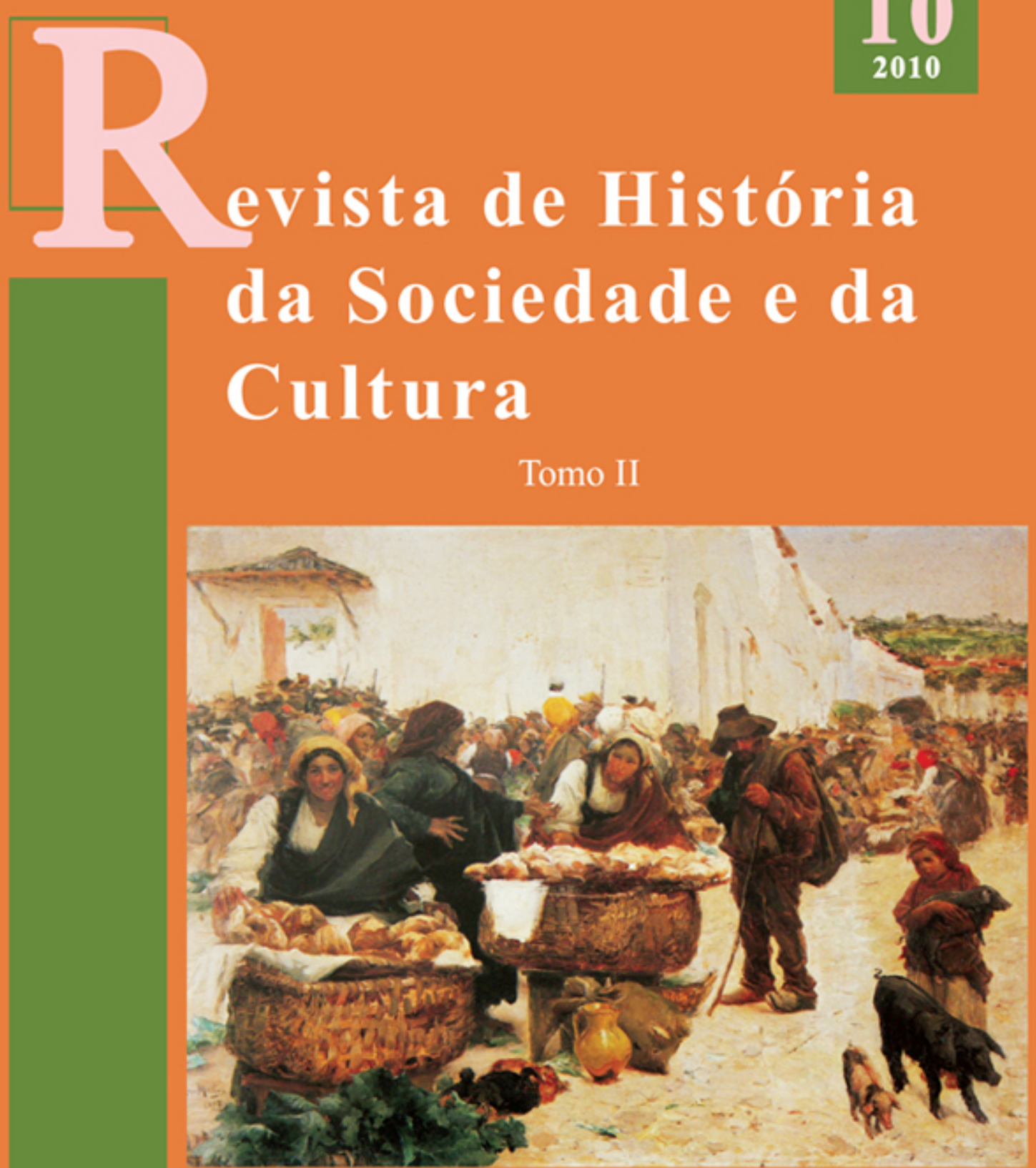

Centro de História da Sociedade e da Cultura Universidade de Coimbra

Coimbra 


\title{
Famílias em Coimbra nos séculos XVIII e XIX
}

\author{
Guilhermina Mota \\ Universidade de Coimbra \\ Centro de Estudos da População, Economia e Sociedade \\ guimota@mail.telepac.pt \\ Texto recebido em/ Text submitted on: 28/02/2010 \\ Texto aprovado em/ Text approved on: 25/04/2010
}

Resumo/Abstract:

Este artigo apresenta um quadro da cidade de Coimbra e das suas famílias nos séculos XVIII e XIX. O trabalho tem como fontes sobretudo listas de população de carácter eclesiástico. Estabelece comparações na organização das famílias nos diversos espaços da cidade e diversos grupos sociais.

This paper provides a picture of 18th and 19th-century Coimbra and families. Its core sources were the lists of population of ecclesiastical nature. It compares the distribution of households over different parts of the city and by social group.

Palavras chave/Keywords:

Família; História das cidades; Coimbra.

Family; The history of cities; Coimbra. 
Coimbra, cidade antiga, tem na Época Moderna uma malha urbana densa, recortada por ruas, ruelas, becos e quelhas, estreitas e tortuosas, com as casas acastelando-se encosta acima, ou amontoando-se na parte baixa, mais insalubre, e à mercê das inundações do rio. Marca da urbe é ainda a penetração do campo pelo meio do casario, com as suas hortas, quinchosos e quintais, com os animais pelas ruas desafiando as posturas camarárias ${ }^{1}$. Também os extensos bens fundiários de mosteiros e colégios ocupam uma boa parte da área citadina e acentuam-lhe o ar campestre. Só nas últimas décadas do século XIX se produzem grandes transformações de ordem urbanística e assim Coimbra mantém-se até tarde como uma "pequena, romântica e bucólica cidade"2.

A população da cidade tem fundas raízes no solo, pois, embora maioritariamente se dedique a actividades urbanas, não deixa em muitos casos de se ocupar também da lavoura das terras existentes pelos arrabaldes e pelo termo. A fidalguia e a nobreza conimbricenses vivem nas casas que têm na cidade, mas também nas quintas espalhadas pelos aros, quintas cuidadas que lhes servem para assegurar o estilo de vida "à lei da nobreza", mas que, geridas com lógica de mercado, lhes asseguram também um bom rendimento, e quintas em cujas casas os nobres muitas vezes deixam ficar as suas mulheres e onde elas definham, enquanto na cidade eles se ocupam dos negócios do concelho e da política local tudo condimentado com "vinho, rameiras e comédias"3. O calendário agrícola impõe-se em certa medida à vida citadina: as férias da Câmara fazem-se quando chega o tempo das colheitas, a Universidade e o tabelionado interrompem para as vindimas ${ }^{4}$.

1 Ainda em Novembro de 1841 a Câmara Municipal reiterava a proibição da permanência de porcos na cidade. Anais do Município de Coimbra, 1840-1869. Nota preambular, síntese e índices por Armando Carneiro da Silva. Coimbra, 1972-1973, p. 47.

2 ROQUE, João Lourenço - Coimbra no século XIX: breves «imagens» urbanísticas e sociais. In Homenagem da Misericórdia de Coimbra a Armando Carneiro da Silva (1912-1992). Coord. Maria José Azevedo Santos. Coimbra: Santa Casa da Misericórdia; Viseu: Palimage, 2003, p. 23.

3 SOARES, Sérgio Cunha - O município de Coimbra da Restauração ao Pombalismo: poder e poderosos na Idade Moderna. Vol. I. Geografia do poder municipal. Coimbra: Centro de História da Sociedade e da Cultura, 2001, p. 245.

4 Ver OLIVEIRA, António de - A vida económica e social de Coimbra de 1537 a 1640. Coimbra: Faculdade de Letras da Universidade de Coimbra, 1971, vol. I, p. 327-330. 
A forte ligação entre o campo e a cidade, sem ser uma especificidade coimbrã, pois as cidades até ao século passado têm grande dependência das áreas agrícolas envolventes, ajuda a definir-lhe o carácter. Em volta da urbe impera a vida rural: aí se situam as quintas, os casais, as hortas que abastecem o mercado, as vinhas, os olivais, os lagares, os palheiros. Aí encontramos lavradores, seareiros, trabalhadores, moleiros, carreiros, cavadores, feitores e criados de quinta, sem prejuízo da presença aqui e ali de artesãos, ou mesmo de gente de condição que tem as suas quintas como primeira residência. Por exemplo, o cidadão Bernardo António de Andrade reside em 1778 na sua quinta ao Almegue com duas criadas e três criados; o fidalgo da Casa Real e mestre-de-campo do terço da comarca de Castelo Branco, Miguel Osório Cabral Borges da Gama e Castro, vive na Quinta das Lágrimas a partir do seu casamento em 17845; o lente de Química Tomé Rodrigues Sobral, que fora colegial de São Paulo, mora pelo menos desde 1805 na Quinta da Cheira ${ }^{6}$, onde morre em 1829; D. Luísa Benedita Pinto Furtado está na sua Quinta da Arregaça ${ }^{7}$ em 1875, com três criadas e um criado, assim como, no mesmo ano, D. Rita de Albuquerque está na sua Quinta das Varandas ${ }^{8}$ com o capelão e cinco criadas.

Coimbra, cidade dual, com a Alta, dominada pela Universidade e pelo estudo, onde habitam professores, estudantes e pessoas de estatuto social elevado; e a Baixa, que é o mundo do trabalho onde se concentram os homens de negócio, os mercadores, a gente de ofícios e de serviços. Cidade dual, é verdade, mas a afirmação não exclui que na Alta existam comerciantes e muitos artesãos, entre os quais, sapateiros, alfaiates, carpinteiros, barbeiros, necessários para responder às necessidades dos universitários, mas também

5 Ano a partir do qual, e até 1792, ocupa a provedoria da Misericórdia de Coimbra, sendo depois vereador da Câmara. Ver LOPES, Maria Antónia - Provedores e escrivães da Misericórdia de Coimbra de 1700 a 1910: elites e fontes de poder. Sep. Revista Portuguesa de História. 36, 2 (2002-2003), p. 222. Verifica-se assim que, apesar de ser de fora, pois era natural da Guarda, logo se integrou nas estruturas de poder da cidade, se bem que tivesse sido provedor da Santa Casa por nomeação régia.

6 A sua casa da quinta será incendiada pelo exército francês em 1810, como retaliação por ele ter comandado a Companhia de Artífices Voluntários Académicos, dirigido o fabrico de pólvora no Laboratório Químico da Universidade, e assim contribuído para a expulsão dos invasores efectuada dois anos antes.

7 Dentro da quinta estão também mais dois fogos, de um arrendatário e de um cavador.

8 Quinta onde se encontram mais seis fogos, sendo três deles lares de cavadores. 
às dos eclesiásticos, pois na Alta, para além da Universidade, se situam igualmente o Paço Episcopal e as residências dos cónegos do Cabido. Em contrapartida, a Baixa, caracterizada sem dúvida pela vida laboral, não deixa de acomodar alguns estudantes e lentes ${ }^{9}$, doutores ${ }^{10}$, advogados ${ }^{11}$, médicos ${ }^{12}$, clérigos, um ou outro fidalgo ${ }^{13}$, que convivem paredes meias com a restante população. Se há ruas mais marcadas por uma especialização

9 Por exemplo, em 1745, mora na Rua do Coruche o lente de Medicina Manuel dos Reis e Sousa; em 1778, o muito conhecido Domingos Vandelli, lente da Faculdade de Filosofia, na Rua da Calçada; em 1851, o lente de Direito Francisco Raimundo da Silva Pereira na Rua do Corvo, Francisco de Castro Freire, lente de Matemática, em Montarroio, e António Florêncio Sarmento, lente de Música, na Rua da Moeda.

${ }^{10}$ Em 1778 moram na Baixa: o Rev. Dr. António José Coutinho, na Portagem; o Dr. Sebastião José Afonso da Costa Carvalho (casado com D. Sebastiana Rita de Magalhães Castelo Branco), o Dr. António Dias da Silva, o Dr. Manuel Caetano de Sousa, o Dr. Joaquim Alexandre de Oliveira, tabelião da Câmara, todos na Rua da Calçada; o Dr. Diogo Manuel da Costa e Sousa, na Rua do Sargento-Mor; o Dr. José Joaquim do Amaral, na Rua dos Gatos; o Dr. João Pedro de Vargas Pereira e o Dr. José Marques, ambos no Adro de Baixo; em 1851, o bacharel Adriano Tomás dos Santos Viegas, na Rua dos Sapateiros.

${ }^{11}$ O Dr. Custódio Pacheco de Resende tem residência na Praça em 1778 e, na mesma data, o Dr. Luís da Cunha na Rua do Sargento-Mor e o Dr. Francisco José dos Santos na Rua da Saboaria; em 1851, o Dr. Joaquim Miguel de Araújo Pinto, advogado e tesoureiro da Universidade, na Rua das Padeiras.

${ }^{12}$ Por exemplo, o Dr. Manuel de Sousa Loureiro, que foi médico da Misericórdia, mora na Calçada em 1778; o Dr. António Joaquim de Oliveira mora na Rua das Figueirinhas em 1851, o qual, nesse mesmo ano, integra a comissão encarregada da demarcação do terreno para o Cemitério da Conchada. Ver SIMÕES, A. A. da Costa - Noticia historica dos Hospitaes da Universidade de Coimbra. Coimbra: Imprensa da Universidade, 1882, p. 112.

${ }^{13}$ É certo que os fidalgos que têm as suas moradas na parte baixa da cidade as têm na Rua da Calçada, a rua mais importante da Coimbra moderna, verdadeiro eixo dinamizador da vida económica e política. Na Calçada moram em 1778: o fidalgo João de Magalhães Castelo Branco, homem da governança que foi almoxarife e juiz dos direitos reais. D. Leonor Angélica de Morais Lara e Sousa, viúva do fidalgo da Casa Real Francisco de Morais e Brito da Serra, que foi escrivão da Câmara, vereador, deputado dos Marachões, provedor da Misericórdia, familiar do Santo Ofício e cavaleiro professo da Ordem de Cristo. O fidalgo da Casa de Sua Majestade, natural de Lisboa, Rodrigo da Cunha Manuel Henriques de Melo e Castro (que foi vereador da Câmara, escrivão e provedor da Misericórdia; ver LOPES, Maria Antónia - Provedores e escrivães..., cit., p. 219), que vive com a sogra, D. Mariana Teresa Bray, viúva de um negociante inglês que também foi feitor em Coimbra da Real Fábrica dos Vidros Nacionais (ver CAMPOS, Aires - Indices e summarios dos livros e documentos mais antigos e importantes do Archivo da Camara Municipal de Coimbra. Coimbra: Imprensa da

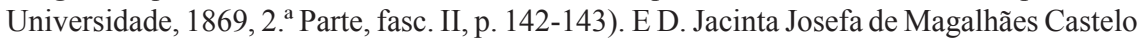
Branco, viúva de João de Miranda Sequeira (sobre o casamento destes últimos realizado em 1716, consulte-se MOTA, Guilhermina - A Igreja, a Mulher e o Casamento no século XVIII. Sep. Mulher: Espírito e Norma. Actas do IV Encontro Cultural de São Cristóvão de Lafões. Coord. Maria Alegria Fernandes Marques. São Cristóvão de Lafões: Associação dos Amigos 
socioprofissional, sobretudo com a presença de mesteirais na Baixinha, o mais comum na ocupação do espaço é a imbricação de malhas sociais e profissionais distintas ${ }^{14}$, possibilitando uma sociabilidade verticalizada ${ }^{15}$. Por outro lado, muita gente vai mudando de casa ao longo da vida, numa aproximação aos locais socialmente mais relevantes à medida que progride o seu nível de vida e a sua posição social, como faz o lente de Medicina, que também foi vereador pela Universidade ${ }^{16}$, José dos Santos Gato, natural de Beja, que começa em 1751, quando era condutário, por residir em São Bartolomeu, mas no fim da vida em 1796 está na Rua das Fangas, uma das artérias principais na época; ou o lente de Medicina José Pinto da Silva, que foi também director dos Hospitais da Universidade e vereador, que começa por morar na freguesia de Santa Cruz em 1786, mora depois na Rua da Ilha e por fim na sua Quinta de Santo António, em Marrocos; e o lente da Faculdade de Filosofia Manuel José Baptista Barjona ${ }^{17}$ que em 1783 se casa e reside primeiro na Baixa, na freguesia de Santa Justa, e depois na Alta, em 1790 no Bairro de São Bento, em 1817 ao Castelo; ou o lente da Faculdade de Filosofia António José das Neves e Melo ${ }^{18}$ que faz um verdadeiro périplo entre 1792 e 1822: Rua do Corvo e Rua de Tinge-Rodilhas

do Mosteiro de São Cristóvão de Lafões, 2009, p. 117) que são os pais de D. Sebastiana Rita citada na nota 10 .

${ }^{14}$ Na mui nobre Rua da Calçada, por exemplo, estão em 1778 os agregados de fidalgos, um lente, doutores, donas, um médico, o administrador dos tabacos, dois licenciados, um tabelião, um padre, o escrivão do eclesiástico, mas também dois boticários, um negociante e oito mercadores, um livreiro, entre diversos mesteirais como seis alfaiates, dois latoeiros, dois cabeleireiros, dois barbeiros, dois sangradores, um sapateiro, um espadeiro, um ferrador, um lavrante, e ainda um vendeiro de vinhos além de outros vinte e cinco fogos cujos cabeças não têm qualquer indicação social ou de profissão.

${ }^{15}$ Ver SOARES, Sérgio Cunha - O município de Coimbra ..., vol. I. Geografia do poder..., cit., p. 269.

${ }^{16}$ SOARES, Sérgio Cunha - Os vereadores da Universidade na Câmara de Coimbra (1640-1777). Sep. Revista Portuguesa de História. 26 (1991), p. 80.

${ }^{17}$ Foi vereador pela Universidade em 1800, integrou o Corpo de Voluntários Académicos em 1808 e era Cirurgião-Mor do Batalhão Académico em 1826-1827; foi preso no ano seguinte, julgado pelos Absolutistas, e perdeu o lugar e ordenado de lente, vindo a acabar os seus dias na cidade de Lisboa em 1831.

${ }^{18}$ Vereador pela Universidade em 1816, inspector e director interino do Jardim Botânico, teve uma carreira académica acidentada, vindo a ser demitido por motivos políticos em 1834 , falecendo no ano seguinte. 
na Baixa, Rua do Loureiro na Alta, Rua da Sofia voltando à Baixa, e por fim, subindo de novo à Alta, mora aos Arcos de São Bento ${ }^{19}$.

Em busca dessa cidade a dois tons, irei tentar esboçar quadros de vida familiar em diversos espaços da cidade e em diversos grupos sociais, atentando em duas freguesias da Baixa, a de São Bartolomeu em 1778 e a de Santa Cruz em 1851 e em duas freguesias da Alta, a de Almedina e a de São Pedro, ambas em 1801, adiantando algumas imagens da vida familiar na freguesia da Sé Velha ${ }^{20}$ em 1875, ancorada sobretudo em listas nominativas. As listas nominativas são listas de pessoas, com indicação dos respectivos nomes, e que são muito importantes para o estudo da organização familiar, porque as pessoas não se encontram lançadas nos cadernos de forma avulsa, mas integradas nos fogos em que vivem. Neste caso são róis de natureza eclesiástica, sobretudo destinados à desobriga da confissão pela Páscoa ${ }^{21}$.

${ }^{19}$ Todas as informações até agora aduzidas foram colhidas quer em registos paroquiais da cidade, quer em listas de população adiante citadas; informações sobre os professores da Universidade de Coimbra, em Memoria professorum Universitatis Conimbrigensis 1772 -1937. Direcção de Manuel Augusto Rodrigues. Vol. II. Coimbra: Arquivo da Universidade de Coimbra, 1992, obra que voltarei a utilizar mais à frente.

${ }^{20}$ Ou freguesia de São Cristóvão que é designada à época por Sé Velha por a sede da paróquia se localizar então na antiga catedral; será de 1920 em diante freguesia de Almedina. Utilizarei um rol de confessados datado de 1875, que se guarda no Seminário Maior da Sagrada Família. Deixo o meu reconhecimento e um preito de homenagem ao Senhor Padre Doutor A. Brito Cardoso a quem devo a amabilidade de me ter facultado a consulta deste documento. $\mathrm{O}$ rol enferma de uma distorção que não permite uma análise completa. De facto, o número de fogos está muito inflacionado, pois o Censo de 1864 (publicado por ALBUQUERQUE, J. da Costa Brandão e - Censo de 1864: relação das freguezias do continente e ilhas; população, sexos, fogos; divisão civil, judicial, militar e ecclesiastica. Lisboa: Typographia da Gazeta de Portugal, 1866, p. 48) refere 589 fogos na freguesia da Sé Velha, ao passo que o rol por mim analisado consta de 864 . Pelo contrário, o número de habitantes é mais elevado no censo (2885) do que no rol (2564), donde resulta que a média de habitantes por fogo é de 4.8 no censo e de 2.9 no rol. Penso que a forte inflação de fogos resulta de mau entendimento do conceito de fogo por parte do pároco, sobretudo ao considerar sempre como fogos os quartos dos estudantes que são muitos na zona da cidade abrangida pela freguesia. Assim, o estudo da dimensão, estrutura e composição dos agregados fica claramente comprometido. A fonte permite, no entanto, conhecer a distribuição socioprofissional nesse espaço da cidade e permite avaliar alguns aspectos da composição dos grupos domésticos.

${ }^{21}$ Estas listas encontram-se no Arquivo da Universidade de Coimbra. As listas das freguesias de São Bartolomeu e de Santa Cruz são róis de confessados e comungados, as de Almedina e de São Pedro, embora também redigidas pelos respectivos párocos, destinavam-se a efectuar uma contagem de população; ver MOTA, Guilhermina - Estruturas familiares no mundo rural: grupos domésticos no bispado de Coimbra em 1801. Coimbra, 1990. Sep. Revista Portuguesa de História. 24 (1989), p. 2-9. O rol de confessados de Santa Cruz de 
Família será aqui considerada não no seu sentido lato, conjunto de pessoas ligadas por laços de parentesco conscientes, ou seja, até onde a memória os identifica como tal, mas no sentido restrito de agregado familiar, de grupo doméstico, de fogo, na designação da linguagem administrativa ${ }^{22}$. O critério primeiro de classificação desta unidade familiar é a corresidência, a partilha do mesmo espaço físico, o viver debaixo do mesmo tecto. Por isso a frequente interpenetração dos conceitos de casa e de família e a centralidade que a noção de "casa" tem nas concepções e na organização social ao longo do tempo, revestindo-se de uma forte carga, material e simbólica.

Mas casa e família nem sempre coincidem. A par de famílias formadas por um casal, com ou sem filhos, acompanhado ou não por parentes que vivem nas suas residências, há situações familiares muito diversificadas: há famílias privadas de habitação; há quem detenha mais que uma morada; há famílias que recebem estranhos no seu seio, por razões de ordem laboral ou por necessidade económica; há quem se encontre em instituições, convivendo com pessoas que antes desconheciam, ou por opção, caso de mosteiros ou de colégios, ou por contingências da vida, caso de hospitais, de recolhimentos ou de cadeias.

Os róis estudados abrangem a população que depende da jurisdição paroquial. Registam os fogos que comportam famílias ou pessoas singulares, mas também os que constituem algumas instituições.

Em 1778, localizada na freguesia de São Bartolomeu, está a Cadeia da Portagem $^{23}$, onde tem a sua residência o carcereiro que vive com a mulher e filhos, uma cunhada e um criado. Residência do carcereiro a que Camilo Castelo Branco também alude, ao descrever os diferentes espaços do cárcere, reportando-se ao ano de 1619:

1851 foi já estudado por Rui Cascão, mas esse estudo foi elaborado sob a perspectiva da observância dos preceitos religiosos por parte da população e não sob a perspectiva da história da família. CASCÃO, Rui - A evolução da prática religiosa na freguesia de Santa Cruz (Coimbra) 1851-1913. Revista Portuguesa de História. 26 (1991), p. 81-110.

${ }^{22}$ Para o entendimento de agregado familiar e metodologia de análise, ver MOTA, Guilhermina - Estruturas familiares..., cit.

${ }^{23}$ Sobre as condições, péssimas, desta cadeia, que perduraram no tempo, veja-se SOARES, Sérgio Cunha - O município de Coimbra..., cit. Vol. III. Práticas e processos da formação camarária. Coimbra: Centro de História da Sociedade e da Cultura, 2004, p. 201-203 e LOPES, Maria Antónia - Pobreza, assistência e controlo social em Coimbra (1750-1850). Viseu: Palimage, 2000, vol. I, p. 525-533. 
"A cadeia, chamada «Portagem», era um quadrilongo de dous andares, com entrada por um pateo escuro. A um lado do pateo corriam as tarimas da guarda; ao centro rompia a escada estreita que levava ao andar superior, e a meia-subida se bifurcava em escadas descendentes para os calabouços ou enxovias. Do outro lado do pateo estava o quarto do official da guarda, paredes meias com a residencia e escriptorio do carcereiro. A sentinella nocturna era feita por tres soldados, e trinta costumava ser ao todo a guarda, que se alojava no pateo, deixando aberto o portão da entrada. As chaves das enxovias e prisões superiores recolhia-se com ellas o carcereiro, ao anoutecer, nos seus aposentos"24.

Na cadeia confessam-se cinquenta e cinco presos e nove presas, disparidade numérica que bem ilustra a diferença de género no que respeita ao crime, embora na época nem só o crime levasse à prisão. As quebras, as dívidas, a vadiagem, a incúria e até a recusa em aceitar certos cargos onerosos, para lá conduziam muitos e, nestes casos, a própria natureza das infracções aponta sobretudo para um universo masculino ${ }^{25}$.

Com a extinção das Corporações Religiosas em 1834, o Mosteiro de Santa Cruz reverte com todos os seus bens para a fazenda pública. Depois, nele são instalados diversos serviços e repartições, como a secretaria da administração do distrito, a Câmara Municipal, a casa de audiência, a cadeia, a administração do correio. Por Lei de 30 de Julho de 1839, a Câmara fica na posse do edifício do extinto mosteiro, do laranjal, da horta e da encosta contígua ao edifício ${ }^{26}$.

O município de Coimbra, a quem no ano de 1839 é entregue a administração da roda dos expostos do concelho, aí albergará a Casa da Roda ${ }^{27}$, transferida em 1848 de Montarroio para o dormitório da Senhora do Pilar

${ }^{24}$ Lucta de gigantes: narrativa historica. Porto: Typographia do Commercio, 1865, p. XVII-XVIII.

${ }^{25}$ Neste rol, os únicos presos com alguma indicação para além do nome e da morada, são quatro soldados. Sobre os presos da Cadeia da Portagem nessa época, ver LOPES, Maria Antónia - Pobreza, assistência e controlo social..., cit., p. 537-568.

${ }^{26}$ Informação histórica acerca do edifício de Santa Cruz. In Anais do Município..., cit., p. 103-105. Ver também MADAHIL, A. G. da Rocha - Inventário do Mosteiro de Santa Cruz de Coimbra à data da sua extinção em 1834. O Instituto. 101 (1943), p. 445-573.

${ }^{27}$ Sobre a administração dos expostos e da Casa da Roda, consulte-se, para este período, ROQUE, João Lourenço - Classes populares no distrito de Coimbra no século XIX (1830- 
do antigo mosteiro. Na Casa vamos encontrar em 1851 a rodeira, dez amas - duas em idade bastante avançada e por isso amas-secas -, duas criadas, um criado e cinco expostas. Atente-se que estas últimas não são meninas em criação, pois três são já adultas e duas têm oito anos de idade, devendo pois estar ao serviço da casa. Neste ano entram na Roda 683 expostos $^{28}$, número avultado a cujas necessidades as amas internas com dificuldade responderiam. Na Casa vive ainda o empregado da Roda com a sua família e duas criadas.

O antigo mosteiro não foi aproveitado somente para instalação de serviços, conhecendo outras formas de rentabilização. Em Abril de 1837 convencionou-se que a Câmara administrasse as partes do edifício ainda não utilizadas, arrendando tudo aquilo a que aparecessem pretendentes. Assim se retalharam alas do edifício e se arrendaram casas, quartos, lojas, celeiros, a horta ${ }^{29}$ e até o Claustro das Limeiras chegou a ser usado para recolha de gado $^{30}$. Em 1851, vemos por isso instalados numa das suas dependências, com as respectivas famílias, o administrador do correio $^{31}$ e um empregado da Câmara, assim como deparamos com o corredor de S. Francisco e o do Noviciado divididos em vários fogos, onde moram duas donas $^{32}$, um negociante, um bedel ${ }^{33}$, um estudante, um comissário, um oficial do correio ${ }^{34}$ e um empregado de obras públicas.

Anos mais tarde, em 1875, estão listadas na freguesia da Sé Velha as seguintes instituições:

O Colégio das Órfãs e o Colégio dos Órfãos ${ }^{35}$, instalados no edifício do antigo Colégio da Sapiência, e que para lá haviam sido transferidos em 1842,

-1870): contributo para o seu estudo. Coimbra, 1982. (Tese de doutoramento policopiada).

Vol. I, t. II, p. 707-754 e 869-901.

${ }^{28}$ ROQUE, João Lourenço - Idem, p. 732.

${ }^{29}$ Arquivo da Câmara Municipal de Coimbra - Arrematações e arrendamentos. Livros IX e X.

${ }^{30}$ Anais do Município..., cit., p. 194n.

${ }^{31}$ António Lopes de Sá Esteves, que aí arrendara, em 16 de Junho de 1850, duas casas e três quartos por 26.305 rs.

32 Uma delas, D. Maria José Chaves, arrendara aí uma casa por 19.250 rs na mesma data.

${ }^{33}$ Manuel Teófilo Barreto, que arrendara aí uma casa por 19.250 rs na mesma data.

${ }^{34}$ Alexandre da Fonseca e Silva, que arrendara aí na mesma data uma casa por 8.000 rs.

${ }^{35}$ Sobre o Colégio dos Órfãos, o Colégio das Órfãs e o Asilo da Infância Desvalida, consultar LOPES, Maria Antónia - Pobreza, assistência..., cit., p. 333-388 e 416-423 e ROQUE, João Lourenço - Classes populares..., cit., p. 754-769 e 901-913. 
o primeiro a partir do antigo edifício da Misericórdia na Rua do Coruche e o segundo de uma casa na Rua dos Coutinhos onde fora inaugurado em 1804. No Colégio das Órfãs vivem a regente, uma mestra, uma ajudante, uma porteira, uma roupeira, trinta e três alunas e quatro criadas $^{36}$, no dos Órfãos, um vice-reitor, um professor, um despenseiro, cinquenta e um alunos e nove criados $^{37}$.

Outra instituição é o Asilo da Infância Desvalida, estabelecido no antigo Colégio de Santo António da Pedreira ${ }^{38}$, que conta com a regente, duas ajudantes, doze alunas e duas criadas. Inicialmente, o Asilo tinha doze alunos, seis de cada sexo, e só acolhia as crianças durante o dia. Depois, o número de alunos cresceu e no ano referido estão já criadas duas classes de asilados, uma delas de internato, reservada para meninas.

Inscrita como "Colégio da Estrela" está a habitação onde vive o Bispo de Macau, D. Manuel Bernardo de Sousa Enes, com quatro comes e três criadas. Este lente de Teologia em 1866 havia arrendado o edifício da Estrela e aí fundado o Colégio de Educação e Ensino Secundário da Estrêla que chegou a ter alguma projecção. Nomeado bispo de Macau em 1874, suprimiu o colégio no fim do ano lectivo de 1873-1874 ${ }^{39}$, mas, por inércia, no rol ainda se mantém a sua designação.

No Seminário Diocesano, o pároco apenas especifica o vice-reitor António José da Silva, o lente de Teologia Dr. António Bernardino de Meneses, que era professor no Seminário, e os criados, deixando uma referência à desobriga de todos os outros habitantes dita "em globo".

Com a simples denominação de "Ursulinas", mas vazio de pessoas, está o fogo n. ${ }^{\circ} 827$. O prior refere-se ao Real Colégio Ursulino das Chagas

${ }^{36}$ Em 1823 dão entrada no Colégio as primeiras doze meninas e o pessoal da casa é constituído pela regente, por uma mestra, uma porteira, duas criadas, uma servente. LOPES, Maria Antónia - Pobreza, assistência ..., cit., p. 378-380.

${ }^{37}$ O Colégio abriu "com a entrada de 12 meninos, vice-reitor, porteiro, comprador, cozinheiro e moço". LOPES, Maria Antónia - Idem, p. 335. Como se verifica, nestes dois colégios, o claro aumento do número de alunos não foi acompanhado por um aumento proporcional do número de professores e funcionários.

${ }^{38}$ O pároco designa-o mesmo por Colégio da Pedreira.

${ }^{39}$ VASCONCELOS, António de - Escritos vários. Coimbra: Arquivo da Universidade de Coimbra, 1987, vol. I, p. 278. 
de Coimbra, localizado no extinto Colégio de São José dos Marianos ${ }^{40}$ desde 1851, colégio de religiosas que não dependem da autoridade paroquial, e que por isso não são aqui arroladas para os sacramentos, pois têm o seu próprio padre confessor.

Intitulado ainda como tal, aparece o antigo Colégio de São Pedro ${ }^{41}$, à data já uma ala dos edifícios da Universidade e onde apenas mora o reitor, visconde de Vila Maior ${ }^{42}$, com a viscondessa sua mulher, um escudeiro e duas criadas.

O edifício do Jardim Botânico, alojado no antigo Colégio de São Bento e por isso aqui denominado Jardim de São Bento, não é só o local de trabalho de um conjunto de pessoas, mas também a sua própria morada. Morada, antes de mais, do seu director, o lente da Faculdade de Filosofia Dr. Júlio Augusto Henriques ${ }^{43}$, que nele vive com a mulher e duas criadas. Morada também do Dr. Francisco Augusto Correia Barata, lente da mesma Faculdade, com um irmão estudante militar e uma criada, do jardineiro-chefe Adolfo Frederico Möller, com a mulher e uma criada, de um jardineiro, do estufeiro, de um carpinteiro, de quatro cavadores e de três pessoas sem qualificação profissional, todos com suas famílias.

Há ainda fogos não familiares, como as quintas, onde estão só feitores, quinteiros, carreiros, trabalhadores e criados, como acontece, em 1778, com a quinta do lente de Medicina, que foi também vereador, António José da Silva, morador na Rua dos Estudos; com a quinta do advogado, familiar do Santo Ofício e cidadão, Custódio Pacheco de Resende, que vive na Praça; com a Quinta das Canas dos Sá Pessoa que têm casa na Rua das Fangas; e com a Quinta da Várzea do fidalgo Aires de Sá e Melo que então se encontra na

${ }^{40} \mathrm{O}$ edifício deste colégio estava desde 1837 ocupado pelo Hospital de São Lázaro e a sua entrega às religiosas ursulinas provocou grande contestação por parte da Faculdade de Medicina. Sobre a instalação do colégio das Ursulinas em Coimbra, ver VAQUINHAS, Irene Maria - O Real Colégio Ursulino das Chagas de Coimbra: notas para a sua história. Coimbra, 1997. Sep. Revista Portuguesa de História. 31, 2 (1996), p. 427-447.

${ }^{41}$ Este colégio foi extinto por decreto de 16 de Julho de 1834, sendo todos os seus bens incorporados na fazenda da Universidade. VASCONCELOS, António de - Escritos..., cit., p. $183-184$ e 204-206.

${ }^{42} \mathrm{O} 2 .^{\circ}$ Visconde de Vila Maior, Júlio Máximo de Oliveira Pimentel, foi reitor da Universidade de Coimbra entre 1869 e 1884, ano da sua morte.

${ }^{43}$ Este ilustre professor e insigne botânico continuará a habitar no $1 .^{\circ}$ andar do edifício até ao fim da vida, falecendo em 1928 com noventa anos. 
corte onde foi secretário de Estado dos Negócios Estrangeiros e da Guerra ${ }^{44}$. Anos depois, em 1851, o mesmo ocorre na Quinta das Lágrimas do fidalgo Miguel Osório Cabral de Castro ${ }^{45}$, que vive na Couraça de Lisboa, onde mora o feitor, quatro criados, um carreiro e um moleiro; na Quinta de Reveles onde estão o feitor, quatro criadas, cinco criados e dois trabalhadores; na quinta da Copeira, dos fidalgos do Sardoal, com três fogos de trabalhadores; ou na de D. Maria da Luz Serra, em Coselhas, com um criado.

Caso singular o de D. Antónia Bárbara Benedita de Queirós, viúva de Dionísio de Macedo Guimarães ${ }^{46}$, que se ausenta com os filhos, e deixa a sua casa ${ }^{47}$, sita na Rua da Calçada, entregue ao Padre Domingos de Macedo, sobrinho do seu falecido marido, que nela vive com três criadas em 1778 .

Mas os agregados são, no seu cerne, famílias, ou seja, reúnem pessoas ligadas pelo sangue ou pelo casamento. São núcleos de reprodução biológica e de reprodução social. É no seu seio que se vem ao mundo e se conduz o processo de criação e de educação das crianças e dos jovens. Cobrem também as necessidades de amparo e de protecção a órfãos, a idosos, a doentes e a gente com incapacidades diversas. Esse amparo era determinante numa época em que o Estado não criara ainda a segurança social e não havia lares de terceira idade.

Na cidade de Coimbra, vemos a viúva de um sapateiro, moradora no Romal, acolher uma sobrinha órfã em 1778 e, no mesmo ano e local, um

${ }^{44}$ Este importante fidalgo, cavaleiro professo da Ordem de Cristo, foi em Coimbra vereador e escrivão da Misericórdia antes de rumar a Lisboa (LOPES, Maria Antónia Provedores e escrivães..., cit., p. 214-215). Foi accionista da Companhia Geral da Agricultura das Vinhas do Alto Douro, com direito a voto (ver MACEDO, Jorge Borges de - A situação económica no tempo de Pombal: alguns aspectos. Porto: Livraria Portugália, 1951, p. 267).

${ }^{45}$ Neto do fidalgo referido na nota 5 , foi par do reino, deputado às Cortes, vereador da Câmara de Coimbra, provedor da Misericórdia (1869-1870).

${ }^{46}$ Este mercador (falecido em 2 de Outubro de 1774), natural de Mosteiro de Souto, termo de Guimarães, chamado para Coimbra por seu tio (o mercador, almotacé e cidadão Filipe de Macedo Guimarães), faz na cidade um notável percurso de ascensão social pois torna-se cidadão, como almotacé, em 1755, e escrivão proprietário da Câmara em 1758 (SOARES, Sérgio Cunha - O município de Coimbra ..., cit., vol. II. Sociologia do poder..., cit., p. 313). É cavaleiro professo da Ordem de Cristo e alcança um bom casamento em 1762 com a referida D. Antónia, filha do licenciado Gonçalo Borges de Queirós, de Provesende.

${ }^{47}$ Casa que Dionísio de Macedo Guimarães constituiu, adquirindo em 1759 umas casas por 3.000 cruzados, as quais alargou em 1765 por compra de umas casas contíguas. SOARES, Sérgio Cunha - O município de Coimbra ..., vol. I. Geografia do poder..., cit., p. 267. 
sapateiro viver com a mulher atingida pela loucura. Um trabalhador da Rua de Cima vive em 1851 com uma filha demente e dementes estão também a mulher e uma filha de um sapateiro morador na Rua dos Anjos em 1801. $\mathrm{Na}$ mesma rua e ano uma viúva tem uma filha cega, assim como tem um sapateiro do Adro de Baixo em 1778 e um século depois duas viúvas, uma na Rua do Norte, outra na Rua das Esteirinhas; e uma mulher moradora na Estrada da Arregaça tem um irmão cego. Em 1851 é uma mulher da Rua da Gala que tem a mãe cega em sua casa, assim como tem um homem da Rua de Cima uma irmã, e uma viúva da Rua de Baixo uma filha.

Mas nem só os familiares acolhem os mais fragilizados. Em 1851, uma viúva tem um órfão de 15 anos no seu domicílio no Quintal; em 1778, o administrador dos tabacos João Dias Forte tem em casa na Rua da Calçada quatro órfãs, o que talvez signifique serviço doméstico velado, pois com mulher e sete filhos apenas tem um criado, que certamente estava ao serviço da actividade profissional do amo. O mesmo se passará em casa de um mercador que reside na Praça com uma órfã e uma criada, e em casa de uma mulher, sogra de um sapateiro, que mora com a família e uma órfã em Santa Clara.

Outros acomodam pessoas com problemas de saúde, como o faz o Dr. Custódio Pacheco de Resende que, entre as pessoas do seu agregado, conta com um entrevado. No fogo de um oleiro da Rua da Moeda em 1851 há dois aleijados e, na mesma data, um oleiro morador ao Colégio Novo, uma viúva de um pedreiro e o sineiro João dos Santos, nos seus lares recebem pessoas cegas. Um cordoeiro, que habita com a família na Rua dos Sapateiros, alberga uma mulher surda, e um trabalhador da Rua Velha junto dos seus tem um homem mudo. Anos depois, em 1875, uma mulher com os seus filhos abriga um mentecapto aos Palácios Confusos. Nem em todos os casos a decisão de favorecer estas pessoas terá sido guiada pela solidariedade pois elas podiam ser encaradas, à medida das suas capacidades, como um recurso laboral, e talvez até como fonte de algum rendimento, mais que não fosse o que podia advir do auxílio da Misericórdia ${ }^{48}$.

${ }^{48}$ Sobre o socorro prestado pela Santa Casa da Misericórdia à doença e à invalidez, ver LOPES, Maria Antónia - Pobreza, assistência ..., cit., vol. II, p. 25-67. Sobre o socorro prestado à pobreza nos séculos XVII e XVIII, ver também LOPES, Maria Antónia - Imagens da pobreza envergonhada em Coimbra nos séculos XVII e XVIII: análise de dois róis da Misericórdia. In Homenagem da Misericórdia de Coimbra ..., cit., p. 93-123. 
Da dificuldade que estas pessoas teriam de subsistir por si dá-nos conta o facto de, em 1851, somente um aleijado na Rua Velha e dois entrevados, da Rua das Padeiras e da Rua da Moeda, serem cabeças de fogo, e mesmo nesses casos acompanhados por familiares. A própria quantia que a Santa Casa atribuía aos entrevados, por exemplo, embora "não despicienda, não era suficiente para a manutenção de um indivíduo" ${ }^{49}$. Apenas duas mulheres, uma na condição de entrevada, moradora no Romal em 1778, e outra invisual, moradora na Rua da Gala em 1851, vivem mesmo sozinhas.

Constituir família não era fácil. No passado, nem todos os Conimbricenses se casavam e, mesmo para os que se casavam, o estabelecimento em casa própria implicava disponibilidades materiais que não estavam ao alcance de todos.

No fundo da escala social encontram-se os mendigos, muitas vezes vagabundos, que andam pelas ruas, alguns pedindo por padres-nossos e ave-marias para as almas. Sem amparo familiar, sem morada certa, abrigam-se pelas quintas, em palheiros, em estrebarias, em tendas de oleiros e nos fornos de pão ou de cal ${ }^{50}$ no frio do Inverno, no tronco dos pobres, em estalagens e lojas particulares que o exercício da caridade lhes facultava, locais onde muitas vezes a morte os surpreende, um pouco por toda a cidade e nos seus arrabaldes. Alguns nem esse aconchego conseguem e ficam-se mesmo em plena rua, debaixo de um arco, à porta das igrejas, nos pátios dos mosteiros ${ }^{51}$.

Mas há quem os acolha no seu lar, sem com eles ter qualquer relação de parentesco. O tabelião Manuel Lopes da Cruz Freire teve aboletados em sua casa, nas Ameias, uns vagabundos que tiveram uma menina na noite de Natal de 1812 e em 1760 morre em casa do poderoso fidalgo Manuel de Sá Pereira ${ }^{52}$, na Rua da Ilha, um mendigo que nela assistia. E há quem

${ }^{49}$ LOPES, Maria Antónia - Pobreza, assistência ..., cit., vol. II, p. 55.

${ }^{50}$ Pode apreciar-se um destes fornos na pintura que José de Campos Contente fez em 1926 de um forno de cal situado no Alto de Santa Clara. Ver Coimbra e seus pintores nas colecções da cidade. Coord. e prefácio de Adília Alarcão. Lisboa: Instituto Português de Museus, 2001, estampa 13.

${ }^{51}$ Informações colhidas nos registos de óbitos das freguesias da cidade entre 1700 e 1820. Este quadro da mendicidade persiste pelo século XIX como verifica também ROQUE, João Lourenço - Classes populares..., cit., p. 770-806 e 913-948; e Coimbra no século XIX..., cit., p. 46-60.

${ }_{52}$ Este fidalgo, senhor dos morgados do Sobreiro e Condeixa, ocupou cargos em todos os poderes: foi vereador, mestre-de-campo dos Auxiliares, escrivão e provedor da Misericórdia 
viva mesmo com eles: em 1851, um oleiro da Rua da Moeda ampara três mendigos, e uma mulher moradora no Quintal dois mendigos e um cego; um sapateiro da mesma rua, uma viúva da Rua da Gala e uma mulher moradora na Rua de Cima têm pobres em sua casa, assim como tem o chantre da Sé em 1801 na Rua Larga. O seu acolhimento pode traduzir a vontade de bem-fazer, a qual se harmoniza com uma visão favorável do mendigo que também se manifesta em outras atitudes. Por vezes, as pessoas pedem para ser acompanhadas por mendigos até à sua última morada, deixam-lhes esmolas em disposições testamentárias e, por exemplo, em 1799, um importante homem de negócio da cidade, Manuel Fernandes Guimarães ${ }^{53}$, escolhe, por devoção, um pobre mendigo para padrinho de um dos seus filhos. Mas esse acolhimento também poderá traduzir hospedagem. Não é de afastar totalmente esta ideia pois alguns pedintes seriam bem capazes de prover ao seu sustento. Pese embora tratar-se de uma caricatura, o mendigo da obra Piolho Viajante é descrito como um verdadeiro homem de negócio, com borrador, livro de razão, livro-mestre e caixeiros ${ }^{54}$. Em 1875, dois fogos são mesmo encabeçados por mendigos, um vive sozinho na Rua das Parreiras, o outro mora com a família no Beco da Amoreira. As referências que se colhem nos róis são obviamente muito poucas pois nem sempre os pedintes se enraízam num dado lugar e menos ainda assumem a chefia de um agregado ${ }^{55}$.

Sem ligações familiares estão os expostos ou enjeitados que nestes róis pouco rasto deixam. Na freguesia de São Pedro em 1801 apenas surgem

e do Hospital de São Lázaro, familiar do Santo Ofício, cavaleiro professo da Ordem de Cristo, comendador da redízima de Setúbal. Foi também accionista da Companhia Geral da Agricultura das Vinhas do Alto Douro, com direito a voto. MACEDO, Jorge Borges de A situação económica ..., cit., p. 272.

${ }^{53}$ É um dos negociantes da cidade que em Agosto de 1808 oferece um refresco às tropas inglesas acabadas de desembarcar na costa de Lavos. Ver CARVALHO, Joaquim Martins de - Apontamentos para a historia contemporanea. Coimbra: Imprensa da Universidade, 1868, p. 6-8. Homem rico, proprietário de uma fábrica de damascos, sedas e algodões estabelecida na Rua de João Cabreira, educa as suas quatro filhas no Real Colégio Ursulino da Vila de Pereira, numa aposta clara de ascensão social.

${ }^{54}$ SILVA, António Manuel Policarpo da - O piolho viajante: divididas as viagens em mil e uma carapuças. Ortografia actualizada, prefácio, glossário e notas de João Palma-Ferreira. Lisboa: Estúdios Cor, 1973, p. 67.

${ }^{55}$ Pelo contrário, as referências a mendigos nos assentos de óbitos são abundantes e mostram que os que aqui vêm morrer são oriundos das mais diversas paragens, desde Caminha ao Alentejo e até de Espanha. 
dois, ambos no Couto de Vale de Canas, estando em criação pois são dados como "inocentes", um deles em casa do enfermeiro do Colégio de São Bento; na da Sé Velha em 1875 há um exposto, como criado, em casa do visconde de Monte São na Couraça dos Apóstolos e, em época já bem tardia, ainda aparece na Rua das Cozinhas uma menina de nove dias em casa de uma viúva. É na freguesia de Santa Cruz, em 1851, que deparamos com mais expostos, cinco no edifício da Roda, como já referi, e nove enjeitados, todos na zona urbana, e todos já em idade de trabalhar, sendo pois criados. Embora duas senhoras qualificadas como donas recorram aos seus serviços, é gente de mais baixa condição quem os contrata: um sapateiro, uma engomadeira, uma aguadeira, uma vendedeira, uma parteira, esta última vivendo com uma filha que é ama de expostos; pode dizer-se que neste caso prestavam o serviço completo, a mãe fazia o parto e expunha o recém-nascido na Roda, a filha ia lá buscá-lo para o criar à custa do município.

Menos miseráveis, mas gente de poucos recursos com certeza, serão aqueles, sobretudo mulheres, que partilham as moradas, em convivências mais ou menos estáveis. De facto, um dos aspectos mais salientes da estrutura das famílias em Coimbra ao longo do período estudado é a muito alta percentagem de fogos indeterminados do ponto de vista do parentesco, que representam 11.3\% em São Bartolomeu, 9.6\% em São Pedro, 14.4\% em Almedina e $15 \%$ em Santa $\mathrm{Cruz}^{56}$. É certo que os agregados das pessoas das classes sociais mais elevadas ${ }^{57}$ são muitas vezes indeterminados ${ }^{58}$ pois neles se junta, para além dos parentes, muita clientela, mas não são eles que fazem avultar os números ${ }^{59}$. Se uma boa parte dos agregados indeterminados

${ }^{56}$ Comparem-se estas percentagens com as relativas a um conjunto de freguesias, as quais oscilam entre $0.1 \%$ e $4.4 \%$, indicadas por PEREIRA, Gaspar Martins - Famílias portuenses na viragem do século (1880-1910). Porto: Afrontamento, 1995, p. 96; com a percentagem de $0.9 \%$ encontrada para 26 freguesias da zona centro em MOTA, Guilhermina - Estruturas familiares..., cit., p. 24; e com a de 1.1\% para Penela em MOTA, Guilhermina - Notas para o estudo da família em Penela no século XIX. Sep. A cidade e o campo: colectânea de estudos. Coimbra: Centro de História da Sociedade e da Cultura, 2000, p. 294.

${ }^{57}$ Assim considerei viscondes, fidalgos, um morgado, um desembargador, lentes, doutores, donas, médicos, advogados, estudantes, proprietários, administradores e um comissário.

${ }^{58}$ São indeterminados 30.4\% dos seus agregados na freguesia de São Bartolomeu, 21\% na de São Pedro, $16.7 \%$ na de Almedina e $20.7 \%$ na de Santa Cruz.

${ }^{59}$ Representam respectivamente $15.9 \%, 16 \%, 13 \%$ e $8.5 \%$ dos fogos indeterminados das freguesias de São Bartolomeu, São Pedro, Almedina e Santa Cruz. 
tem unidades conjugais (o que encobre a possível ocorrência de agregados múltiplos nas classes mais elevadas), mais de metade não tem. Dentro destes, um número considerável é constituído por grupos de dois, mas também de três ou até de quatro elementos, todos sem vinculação. O que leva estas pessoas, sem laços visíveis, de sangue ou outros, a juntarem-se será a necessidade de repartir despesas numa luta pela sobrevivência. Tal não exclui eventuais uniões de facto, hetero ou homossexuais, que as próprias condições de vida e de alojamento potenciariam. Alguns terão vindo de fora, de zonas rurais, e por isso sem vínculos familiares na cidade, procurando nos conterrâneos e nos colegas de trabalho, mas encontrando também em conhecimentos de ocasião, os companheiros de casa. São pessoas a quem o pároco, na maioria dos casos, não atribui ofício ou profissão, devendo pois tratar-se de ganhões ou de gente que às tarefas socialmente mais desqualificadas se entrega. As únicas referências, uma vendeira, uma lavadeira, uma aguadeira e uma conserveira, não desmentem tal hipótese.

Comportamento semelhante surge, contudo, na outra ponta da escala social, em residências de lentes na freguesia de São Pedro. Servidos por criados, alguns professores optam pela companhia e convívio com os seus pares, preferência que resulta da identidade cultural e da confluência de interesses, embora também no seu caso se não deixe de considerar que era essa uma opção de vida mais económica. O Dr. José António tem em sua companhia o lente de Cânones Antonino Garcia Pereira ${ }^{60} \mathrm{e}$ o padre Alexandre José Pereira. O lente de Leis António Vieira de Melo e Sampaio ${ }^{61}$ vive com a mulher em casa do Rev. Dr. Luís António com duas criadas e um criado na Rua dos Estudos. Juntos no mesmo fogo surgem o Dr. Rodrigo Rolão Couceiro Pimentel de Almeida, o Dr. José Inácio da Rocha Peniz ${ }^{62}$,

${ }^{60} \mathrm{O}$ qual foi cónego da Sé da Guarda e pertenceu ao Corpo de Voluntários Académicos em 1808.

${ }^{61}$ Que foi provedor da Misericórdia de Coimbra em 1823-1824 e 1827-1828. LOPES, Maria Antónia - Provedores e escrivães..., cit., p. 271.

${ }^{62}$ Foi reitor do Colégio de São Pedro (1786), vereador pela Universidade (1801), major do Corpo de Voluntários Académicos (1808); preso em 1810 e acusado de colaborar com o inimigo, por ter aceitado o cargo de corregedor de Coimbra, faleceu na Cadeia da Relação do Porto; em 1812 foi absolvido postumamente. 
o Dr. João de Magalhães Barbedo e Avelar ${ }^{63}$, todos lentes de Cânones, o Dr. Inácio Roberto de Vasconcelos Bettencourt ${ }^{64}$, lente de Teologia e o Dr. José Correia de Azevedo Morato ${ }^{65}$, lente de Leis, tendo ao seu serviço três criados. Embora o pároco o não refira, penso que estes professores vivem no Real Colégio de São Pedro, pois todos eles eram à data colegiais pedristas. Assim como o Dr. António José Saraiva do Amaral, lente de Cânones, Mariano José de Sarre e Almeida ${ }^{66}$, lente de Teologia e Manuel Joaquim Coelho da Costa Maia ${ }^{67}$, lente de Matemática, que o rol apresenta a viverem em conjunto com dois criados, devem ser colegiais do Real Colégio de São Paulo.

Mas, na generalidade, os lentes residem em casas próprias. Concentram-se nas freguesias da Alta da cidade: em 1801, os fogos que encabeçam representam 3.6\% em São Pedro (são 19) e 4.4\% em Almedina (são 7); em 1875, na freguesia da Sé Velha, chefiam 23 fogos ${ }^{68}$. Na Baixa, apenas há um na Calçada em 1778 e três em 1851 na paróquia de Santa Cruz. Um ou outro vive sozinho, alguns apenas com criados - tal é o caso, por exemplo, do lente de Leis Padre Francisco António Montanha ${ }^{69}$ que vive com um criado no Marco da Feira em 1801, do vice-reitor da Universidade

${ }^{63}$ Cónego doutoral da Sé de Portalegre (1792) e da de Lamego, bispo do Porto (1816), deputado da Inquisição de Coimbra e par do reino (1826). A sua vasta biblioteca, comprada pelo Estado, serviu de núcleo para a Biblioteca Pública do Porto.

${ }^{64}$ Cónego magistral da Sé de Viseu (1792), da da Guarda (1793), da do Porto (1805) e chantre da Sé de Coimbra (1812). Recusou em 1799 o cargo de escrivão da Misericórdia. LOPES, Maria Antónia - Provedores e escrivães..., cit., p. 226.

${ }^{65}$ Que foi vice-reitor do Real Colégio de São Pedro.

${ }^{66}$ Foi secretário, mestre de cerimónias e vice-reitor do Colégio de São Paulo, cónego da Sé de Viseu (1794) e da de Faro (1801).

${ }^{67}$ Cavaleiro da Ordem de Cristo, foi vice-director do Observatório Astronómico e vereador pela Universidade.

${ }^{68}$ Não faz sentido indicar percentagens pois o número de fogos está fortemente inflacionado, como já referi.

${ }^{69}$ De seu nome completo Francisco António Duarte da Fonseca Montanha Oliveira e Silva, cavaleiro professo da Ordem de Cristo, vereador pela Universidade (1783-1785), cónego doutoral da Sé de Braga (1799), da de Coimbra (1809), deputado da Inquisição de Coimbra, desembargador dos Agravos da Casa da Suplicação, vice-reitor da Universidade no período das Invasões Francesas. Esta casa do Marco da Feira onde vivia, e onde faleceu em 6 de Setembro de 1825, legou-a aos Hospitais da Universidade. BARRICO, Joaquim Simões - Noticia historica da Veneravel Ordem Terceira da Penitencia de S. Francisco da cidade de Coimbra e do seu hospital e asylo. Coimbra: Typographia de J. J. Reis Leitão, 1895 , p. 36. 
e lente de Matemática José Monteiro da Rocha ${ }^{70}$ que vive na mesma data na Rua dos Penedos com um criado e uma criada, ou do lente de Teologia Manuel Eduardo da Mota Veiga ${ }^{71}$ com duas criadas na Couraça de Lisboa em 1875 -, mas a maioria com as suas famílias. O abundante recurso a criadagem é uma das marcas dos seus lares, com uma média de 2.5 criados por fogo, chegando em casa do lente de Leis Francisco Coelho de Sousa e Sampaio ${ }^{72}$ em 1801 à soma de oito. Para além dos criados, de ambos os sexos, há uma ama, um escudeiro, um boleeiro e um escravo. A ama e o escudeiro em casa do lente de Cânones Fernando José Saraiva Fragoso de Vasconcelos ${ }^{73}$. O boleeiro está empregado em casa do lente de Medicina Lourenço de Almeida Azevedo ${ }^{74}$ que vive em 1875 com a mulher, três filhos e três criadas, na Rua dos Grilos. O escravo está em casa do lente de Leis José Carlos Barbosa de Sousa ${ }^{75}$, que vive ainda com um criado na freguesia de São Pedro em 1801. Sinal igualmente distintivo dos seus fogos é a dimensão, pois os muito grandes ${ }^{76}$ representam aqui $13.5 \%$, quando no conjunto estudado esses fogos não vão além dos $2.2 \%$, e também a sua complexidade, pois em um terço dos seus lares juntam-se parentes como irmãos, sobrinhos, tias, mães, sogras, cunhados, primos e pessoas sem quaisquer referências, de parentesco ou outras. Por exemplo, em casa do

${ }^{70}$ Director do Observatório Astronómico (1795), vice-reitor da Universidade (1801), cónego magistral da Sé de Portalegre e depois da de Leiria, comendador da Ordem de Cristo (1801), será a partir de 23 de Maio deste ano de 1801 conselheiro do Príncipe Regente e mestre dos seus filhos, cargo que ocupará até 1807 .

${ }^{71}$ Deputado às Cortes a partir de 1868, cónego da Sé de Coimbra, professor no Seminário Diocesano, director da Imprensa da Universidade.

${ }^{72}$ Fidalgo cavaleiro da Casa Real e cavaleiro professo da Ordem de Cristo, foi desembargador da Relação do Porto e dos Agravos da Casa da Suplicação, desembargador do Paço e membro do Conselho de Sua Majestade.

${ }^{73}$ Foi colegial de São Paulo e coronel do Corpo de Voluntários Académicos em 1808.

${ }^{74}$ Entre muitos outros cargos, Lourenço de Almeida Azevedo também exerceu o de vereador e o de presidente da Câmara Municipal de Coimbra, sendo reconhecida a importância da sua acção governativa. Ver OLIVEIRA, Alberto Sá de - Lourenço de Almeida Azevedo administrador municipal. Arquivo Coimbrão. Vol. VIII (1945) p. 1-25. A partir de 1885 vive em Lisboa onde morre em 1891.

${ }^{75}$ Cavaleiro da Ordem de Cristo, foi desembargador e vereador pela Universidade em 1795 .

${ }^{76}$ Entende-se por fogo muito grande aquele que tem dez ou mais pessoas. 
lente de Matemática Francisco de Castro Freire ${ }^{77}$, em Montarroio, em 1851, vivem com ele a mulher e a filha, a mãe, uma irmã, duas tias, um sobrinho, quatro criadas, um criado e um estudante. Não era raro pessoas sem ligação definida viverem nestas casas, como acontece em 1875 com um homem em casa do lente de Medicina António Egípcio Quaresma de Carvalho Lopes de Vasconcelos ${ }^{78}$, na Rua da Trindade, que vive com a mulher, dois filhos e dois criados, com uma mulher na do lente de Medicina Raimundo Francisco da Gama, que vive nos Palácios Confusos com a esposa e a enteada ${ }^{79}$, e com três homens na do lente de Medicina Filipe do Quental ${ }^{80}$, na mesma rua, que vive com a mulher, dois enteados e três criadas. Algumas destas pessoas sem laços definidos no agregado eram estudantes, talvez parentes afastados, como parece ser no caso citado do estudante a viver com Castro Freire (o que se deduz pelo nome), ou filhos de amigos ou conhecidos, os quais, ao colocarem-se à sombra protectora da cátedra, usufruíam de um apoio privilegiado quando vinham para a cidade estudar. Em 1801, assiste um estudante em casa do cónego José Rodrigues Monteiro, lente de Teologia, no Largo do Castelo, e dois em casa de lentes na Rua dos Estudos e no Largo da Feira, só que estes últimos na qualidade de genros ${ }^{81}$. Em 1778 estão dois estudantes em casa do Dr. António Dias da Silva, na Calçada, como estão

${ }^{77}$ Este professor desempenhou também vários cargos e teve múltiplos interesses, pois foi provedor da Misericórdia em 1861-1862, presidente da Junta-Geral do Distrito de Coimbra e presidente do Instituto de Coimbra.

${ }^{78}$ Moço fidalgo da Casa Real, foi deputado por Soure, par do reino e conselheiro em 1880 .

${ }^{79}$ A conhecida poetisa Amélia Janny (1841-1914), que nasceu em Coimbra, e onde sempre viveu, filha do Dr. António José Marques Correia Caldeira, lente de Direito, que desempenhou vários cargos públicos e foi par do reino.

${ }^{80}$ Este lente açoriano, tio de Antero de Quental, exerceu também actividade política, pois foi deputado às Cortes por Ponta Delgada. Ao seu nome (entre outros) ficou ainda ligada a efémera Sociedade de Instrução dos Operários, criada em Coimbra no ano de 1851 (que se propunha "propagar a instrucção pelos filhos do povo"), assim como a Loja maçónica "Pátria e Caridade" fundada para apoiar a dita Sociedade. Ver CARVALHO, Joaquim Martins de - Apontamentos para a historia..., cit., p. 219-224. Anos mais tarde será Venerável da Loja "Liberdade" que chegou a funcionar no edifício do antigo Colégio de Santo António da Estrela. Ver VASCONCELOS, António de - Escritos ..., cit., p. 277-278.

${ }^{81}$ Um deles é António Joaquim de Gouveia Pinto, que virá a ser o autor da obra Exame critico e historico... relativamente aos Expostos, ou Enjeitados ... Lisboa: Typografia da Academia Real das Sciencias, 1828. Vivia com o sogro, João António Bezerra de Lima, professor de Gramática; e na casa vivia também Manuel Gomes Bezerra de Lima, seu cunhado, lente de Leis. 
também dois em 1851 no lar do lente de Direito Francisco Raimundo da Silva Pereira, na Rua do Corvo, um deles seu irmão.

A presença numerosa de estudantes constitui uma das particularidades que caracterizam a cidade, uma vez que tem, ao tempo, a única universidade do país $^{82}$. Muitas vezes os escolares são hóspedes em casa de gente que arredonda os seus rendimentos com o que cobra da pensão oferecida - por exemplo, em 1851, um empregado do Museu, morador na Rua das Figueirinhas, um negociante da Rua da Fornalhinha e um proprietário e negociante, morador na Inquisição -, quando não vive exclusivamente disso, como tudo leva a crer vive uma mulher moradora na Rua do Corvo que tem em casa dois estudantes. Mas muitos, solteiros na maioria, mas eventualmente casados e com filhos, vivem em quartos ou casas arrendadas, com ou sem criados, o que é especialmente verdade no caso da freguesia da Sé Velha, área onde se localiza o Paço das Escolas. Tantos outros vivem em casa de seus pais pois são filhos da terra - filhos de doutores, de negociantes, de funcionários, mas também de empregados e até de um alfaiate -, ou em casa dos sogros quando aqui resolvem matrimoniar-se, como acontece com um estudante natural da Baía que vive em casa do sogro defronte do Paço Episcopal em 1801, ou, cinquenta anos depois, com um estudante genro de um proprietário na Rua da Moeda, para além dos outros dois referidos acima. Também, e como está documentado para os anos de 1801-1802 ${ }^{83}$, viveriam alguns, com certeza de forma transitória, em estalagens, na do Paço do Conde, junto à Igreja do Salvador e na Rua do Loureiro ${ }^{84}$.

${ }^{82}$ Um quadro de vida dos estudantes está traçado por Fernando Taveira da Fonseca no estudo que consagrou à Universidade de Coimbra no século XVIII (A Universidade de Coimbra (1700-1771): estudo social e económico. Coimbra: Por Ordem da Universidade, 1995, p. 327-419). Ver também OLIVEIRA, António de - O quotidiano da academia. In História da Universidade em Portugal. Vol. I, t. II. (1537-1771). Coimbra: Universidade de Coimbra; Lisboa: Fundação Calouste Gulbenkian, imp. 1997, p. 617-692.

${ }^{83}$ QUEIRÓS, Abílio, BANDEIRA, Ana Maria, CAPELO, Ludovina e CASTRO, Maria João - A densidade habitacional universitária na alta de Coimbra (1801-1806). In Alta de Coimbra - Que fututo para o passado? Actas do 2. ${ }^{\circ}$ Encontro sobre a Alta de Coimbra, realizado em 22 e 23 de Outubro de 1994. Coimbra: Grupo de Arqueologia e Arte do Centro, 1995 , p. 242-243.

${ }^{84}$ Não tenho referências aos estudantes alojados em colégios, pois pertencendo estes a ordens religiosas ou militares não cabiam dentro da jurisdição paroquial. 
A lista da Sé Velha de 1875, dado o número avultado de estudantes, poderia possibilitar um rigoroso conhecimento dos contornos das formas de residência estudantil. Infelizmente, quer o registo que o pároco faz dos seus nomes, geralmente em fogos isolados, quer o facto de lançar no fim da lista cinquenta nomes avulsos - não se sabendo pois a que agregados pertencem -, não permitem essa percepção. Como indica, contudo, várias vezes, três ou quatro agregados de estudantes seguidos vivendo sozinhos, pode intuir-se que uma boa parte viveria em quartos de uma mesma casa que alugavam em conjunto ${ }^{85}$, como deixam entrever as seguintes passagens da obra In illo tempore de Trindade Coelho, que veio para Coimbra estudar em 1880:

"No tempo em que eu andava em Coimbra, fui companheiro de casa, no 1. ${ }^{\circ}$ ano, nos Palácios Confusos, de um rapaz ... O cochicho que nós habitávamos tinha só lugar para dois inquilinos. Era ele, no quarto de baixo, e eu só, no andar de cima. Havia uma cozinha que nunca serviu e uma sala de jantar que nunca teve mesa - porque eu ia comer à casa contígua ... e [ele] comia não sei onde ..."

"Uma vez deu-lhe na cabeça para levar da Rua da Trindade, onde eu morava, quanto calçado apanhou à mão às portas dos quartos, pela madrugada" 86

Tal modo de coabitação era, aliás, já corrente no século anterior, uma vez que viver em casa independente só estaria ao alcance dos mais abastados ${ }^{87}$.

Na Época Moderna, a casa, para além de lugar de abrigo, é também muitas vezes uma unidade de produção, desdobrando-se o lar em escritório, loja, tenda ou oficina, onde, quer as pessoas que nela laboram, quer os instrumentos de trabalho, se confundem com os membros da família e com os próprios objectos do quotidiano familiar. Nas casas dos comerciantes assistem caixeiros, nas dos artesãos aprendizes e mesmo oficiais, nas dos boticários vivem por vezes os praticantes de botica, e os advogados e os tabeliães não raro têm consigo os escreventes.

\footnotetext{
${ }^{85}$ Ver OLIVEIRA, António de - O quotidiano da academia, cit., p. 624.

86 "A casaqueida" e "O «Saraiva das forças»".

${ }^{87}$ Ver FONSECA, Fernando Taveira da - A Universidade de Coimbra ..., cit., p. 339.
} 
Também assim ocorre em Coimbra. Em casa do boticário Luís de Sousa Trovão, da Calçada, está em 1778 um praticante de botica e na do boticário António Cândido da Cruz, da Rua Larga, moram dois, um século volvido. Por seu lado, o advogado Francisco José dos Santos em 1778 na sua casa da Rua da Saboaria vive com a família, uma criada, um criado e dois escreventes.

Mas é sobretudo no universo dos ofícios que se faz sentir a presença de estranhos no seio familiar. Esse universo é mais reduzido na Alta, pois em 1801 os fogos de artesãos representam 10\% em Almedina e 20\% em São Pedro (não considerando os fogos da área rural). Por outro lado, os mestres apenas têm consigo três aprendizes e quatro oficiais, ao Castelo, Rua dos Estudos e Rua dos Anjos. Universo mais alargado na Baixa, onde os agregados de artesãos são 97 em São Bartolomeu, ou seja, 28.5\% dos fogos (contando só a área urbana), com dez aprendizes e seis oficiais, mormente pela Portagem, Calçada, Sargento-Mor, Rua dos Gatos. Em Santa Cruz, são 132 fogos de mesteirais numa percentagem de 30.6\% (sem a área rural), com treze aprendizes, sobretudo na Rua das Figueirinhas, Rua da Gala, Rua do Corvo e Rua dos Sapateiros, e com dois oficiais de um tanoeiro na Rua da Moeda. Para o último quartel do século XIX, a presença de oficiais (um) e de aprendizes (dois) é praticamente nula na Sé Velha onde operam 90 artesãos. A leitura destes dados leva a pensar que a composição destes agregados mudou sensivelmente ao longo do período. Comparando os $10 \%$ de fogos com aprendizes de 1778 com os $2.2 \%$ de um século depois, ou os $6 \%$ de fogos com oficiais em São Bartolomeu com o 1.1\% da Sé Velha em 1875 , fica clara a quebra desta convivência doméstica alargada. Os oficiais e os aprendizes deixam de coabitar com os amos, dirigindo-se às tendas e oficinas pela manhã e regressando a casa no final do dia de trabalho, trabalho que executam cada vez mais em troca de um salário e já não de cama, mesa e ensino. Tal situação é bem ilustrada, por exemplo, no caso do alfaiate e comerciante Miguel Dias Barata, que mora em 1875 na Rua das Fangas com a mulher, um filho e um caixeiro, e emprega vinte oficiais, laborando alguns em casa por conta dele ${ }^{88}$. Ou no do tamanqueiro e negociante José António Bizarro que vive em 1851 na Rua dos Sapateiros apenas com

${ }^{88}$ ROQUE, João Lourenço - Classes populares..., cit., p. 157. Este caso mostra também a existência de proto-indústria na cidade de então. 
a família, uma criada e dois aprendizes, e dá trabalho, pelo menos em 1867, a dezasseis pessoas ${ }^{89}$.

O comércio também se localiza principalmente nas ruas da Baixa. Em Santa Cruz, em 1851, os fogos chefiados por negociantes rondam os $8 \%$, percentagem que sobe para $10 \%$ contando apenas a parte urbana, estabelecidos na maioria em Sansão, Rua do Corvo, Rua dos Sapateiros, Freiria. Em S. Bartolomeu, em 1778, os agregados de mercadores ficam-se pelos 4\%, passando de 5\% se excluirmos a parte rural. Concentram-se sobretudo na Rua da Calçada e na Praça. Nas ruas da Alta, a gente de comércio e de negócio é irrelevante do ponto de vista numérico. Em 1801, na freguesia de Almedina, há um negociante por baixo dos Loios e na de São Pedro apenas dois mercadores, um deles na Rua Larga. Na da Sé Velha no último quartel do século XIX aparecem-nos onze sobretudo pela Rua das Fangas, Quebra-Costas e Rua das Covas.

São casas cheias as dos comerciantes, com uma média de seis pessoas por fogo, com muita gente de família (em São Bartolomeu 30\% dos seus fogos são complexos, em Santa Cruz 25.8\% e na Sé Velha 27.3\%), quase todas com criados ou criadas numa média de dois em cada ${ }^{90}$. A maior, com 15 elementos, é a do negociante António Rodrigues Lucas que vive na Rua dos Sapateiros em 1851, com a mulher, uma filha, uma irmã, duas sobrinhas, um sobrinho, um genro, um neto, um irmão caixeiro, mais dois caixeiros e três criadas. De salientar que ao passo que tem em casa consigo um irmão caixeiro, tem um filho fora como caixeiro na casa de um outro negociante, em Sansão, o que mostra a prática de colocar os filhos a fazer o tirocínio noutras lojas.

Inversamente ao que acontece com os lares dos artesãos, aqui, a coabitação de caixeiros com os patrões tem um claro aumento no correr do tempo. No século XVIII em São Bartolomeu, só num quinto das casas dos mercadores residem os seus caixeiros (numa média de 0.4 por fogo),

${ }^{89}$ Idem, p. 164.

${ }^{90}$ A casa que tem mais criados é a do negociante António Manuel Pereira, de 66 anos, solteiro, que vive em 1851 no Terreiro das Olarias com cinco caixeiros, três criados e duas criadas. Este negociante, em 1836, ano de carestia de pão, dispôs-se a vender 30 moios de milho a preço mais baixo que o praticado no mercado para aliviar a situação de fome. Ver ROQUE, João Lourenço - Classes populares..., cit., p. 313 e 466. 
ao passo que em Santa Cruz, em 1851, mais de metade dos agregados de negociantes já os têm em casa (numa média de 0.9 ), percentagem que sobe para 73\% na Sé Velha em 1875 (numa média de 1.2).

O facto de o número de caixeiros aumentar com o tempo fica a dever-se a um maior desenvolvimento do sector comercial no século XIX, com o aparecimento de casas de comércio mais dinâmicas do que as dos mercadores da Baixa setecentista e em que a presença dos caixeiros constitui uma componente de estatuto social. Revela, por outro lado, a fraca diferenciação que ainda persiste entre a esfera doméstica e o espaço de actividade, o que parece ir ao invés do que acontece com os artesãos, onde a separação entre casa e trabalho se acentua no mesmo lapso de tempo. Na sua organização doméstica, todavia, passou a imperar mais uma lógica contratual, recuando a utilização de mão-de-obra familiar, pois, na freguesia da Sé Velha, a mais forte presença de caixeiros coincide com a quase inexistência de parentes, como irmãos, tios ou sobrinhos (apenas surge um), ao passo que em Santa Cruz eles aparecem num quarto das suas casas e em São Bartolomeu num quinto.

De notar que os homens de comércio têm sempre ao longo do período muitas criadas e criados e alguns destes também fariam trabalho nas lojas, como especificamente se diz em 1851 sobre duas "criadas da loja" no fogo de D. Ana Nazaré da Rua do Corvo. Esta ideia é corroborada pela alegação que Josefa do Nascimento, criada do negociante Arnaldo Dacier com loja na Calçada, faz em 1812 numa acção que move ao herdeiro do negociante, falecido em Dezembro de 1808, para obter o pagamento das soldadas. Para fazer o cálculo do montante em dívida, dirá que trabalhou para o seu amo durante 24 anos, fazendo "todo o serviço de casa, de costurar, engomar e fazer todos os arranjos próprios de uma criada grave", e além disto era ela quem "administrava a loja da negociação do dito seu amo", por ele estar já velho e doente, em que "servia de caixeiro pois sabe ler, escrever e contar"

A ideia comum, um tanto impressionista, atribui às sociedades do passado uma organização familiar completamente contrastante com a dos nossos dias. São as famílias ditas tradicionais, remetidas para o lugar mítico das coisas sem espaço nem tempo, por oposição à família moderna, de gestação recente.

\footnotetext{
${ }^{91}$ Arquivo da Universidade de Coimbra - Inventários Orfanológicos. $3 .^{\circ}$ Of. ${ }^{\circ}, \mathrm{m}^{\circ}{ }^{\mathrm{N}} 1$.
} 
Definidas como famílias patriarcais ${ }^{92}$, de grande dimensão, com muitos filhos, multigeracionais, com grande complexidade de parentesco, que viviam em casas onde se acotovelava um mundo de gente, sendo as crianças em grande parte criadas pelos avós que com elas viviam e se tornavam determinantes na sua socialização.

Ora a verdade é que as famílias de Coimbra, ao longo dos séculos XVIII e XIX, quer na Alta da cidade, quer na Baixa, estão, na globalidade, longe de corresponder a esse retrato. Em primeiro lugar, os agregados são de pequena dimensão, não chegando a quatro a média de pessoas por fogo ${ }^{93}$. O predomínio estatístico vai para os fogos pequenos, os que têm até três pessoas, que são metade em São Pedro e Santa Cruz e 57\% em Almedina. Por outro lado, muita gente vive mesmo sozinha - em S. Bartolomeu será um em cada cinco fogos ${ }^{94}$-, sendo mais mulheres do que homens, embora na Alta a proporção tenda mais para o equilíbrio. Vivem sozinhos alguns doutores, poucos, um padre, um verdeal, mas vivem sozinhos sobretudo artífices, trabalhadores, serventes, uma vendedeira e uma tecedeira, de entre a quase totalidade de pessoas a quem os párocos não atribuíram profissão. Sem familiares em casa, mas não inteiramente sozinhos, estão aqueles que vivem com criados, $70 \%$ deles apenas com um. São padres, lentes, doutores

${ }^{92}$ Sendo a utilização deste conceito muito pouco precisa, uma vez que com essa designação apenas se pretende acentuar o peso da autoridade do chefe de família, quando o conceito de família patriarcal se implica, de facto, um poder patriarcal forte, implica também e sobretudo uma organização familiar em que vivem debaixo do mesmo tecto várias unidades conjugais, pois os filhos, à medida que se casam, trazem os seus cônjuges para a casa paterna, mantendo-se intacto o património ao longo do tempo, por os bens passarem indivisos de uma geração a outra, sendo comuns a toda a família. Este tipo de organização familiar não existe em Portugal.

${ }_{93}$ A freguesia de Almedina tem 3.7 de média (160 fogos e 865 habitantes); a de São Pedro 3.8 (respectivamente 522 e 1992); e a de Santa Cruz 3.9 (468 e 1854 respectivamente). A de São Bartolomeu tem 388 fogos e 1252 habitantes, com uma média de pessoas por fogo de 3.2, média demasiado baixa que se fica a dever ao facto de o pároco, como era comum na época, não arrolar os menores de sete anos por não serem ainda de confissão; se acrescentarmos mais $16 \%$ aos efectivos populacionais (percentagem de menores de sete anos calculada a partir dos dados resultantes de 26 freguesias estudadas em MOTA, Guilhermina - Estruturas familiares ..., cit.), a média sobe para 3.7.

${ }^{94}$ Embora estes números tenham de ser matizados por causa da falta dos menores de sete anos. Nas paróquias de São Pedro e de Santa Cruz, as pessoas vivem sozinhas em 11.3\% dos fogos, na de Almedina, em 4.4\%. 
e estudantes, donas, o mestre-escola da Sé (que vive em 1801 com uma ama e um criado), alguns negociantes e mercadores, duas tendeiras, entre outros ${ }^{95}$.

Os agregados muito grandes, com dez ou mais pessoas, são uns meros 2.2\% em São Bartolomeu, menos ainda em São Pedro (1.4\%) e apenas há um em Almedina. Só em Santa Cruz atingem os 3.6\%. Quem reside nestas grandes casas? Em 1778, na freguesia de São Bartolomeu, as mais populosas pertencem ao advogado e cidadão Custódio Pacheco de Resende com 16 pessoas (vive com a mulher, quatro filhas, três filhos, um cunhado, três criadas, um criado e duas pessoas indeterminadas), a D. Mariana Teresa Bray, viúva de um negociante inglês, com 15 (mora com a filha e o genro, um escudeiro, duas amas, quatro criadas, dois criados e três pessoas sem ligação definida), e ao administrador dos tabacos João Dias Forte com 14. Em São Pedro, ao morgado José Correia de Melo Brito e Alvim com 17 elementos (que reside com a mulher, duas filhas, uma tia, um escudeiro, uma cozinheira, cinco criadas, quatro criados e um licenciado de ligação indeterminada) e ao lente Francisco Coelho Sousa e Sampaio com 16 (com a mulher, duas filhas, três filhos, um sobrinho, seis criadas e dois criados). Em Santa Cruz, os maiores são os agregados do negociante António Rodrigues Lucas e do lente Francisco de Castro Freire já referidos, com 15 e 14 elementos respectivamente e, na Rua da Moeda, o do proprietário José da Costa Alves Ribeiro, com 13 (que vive com a mulher, duas filhas, um genro, um sobrinho, dois caixeiros, três criadas e dois criados). Na Sé Velha, com 13, o de D. Ana Leopoldina Botelho de Sampaio e Sousa, moradora na Couraça de Lisboa (com quatro filhas, quatro filhos, três criadas e um criado), o do lente de Matemática Abílio Afonso da Silva Monteiro, da Rua das Fangas (que vive com a mulher, quatro filhas, três filhos e quatro criadas), o do lente de Direito Bernardo de Serpa Pimentel, morador na Rua da Ilha (com a mulher, duas filhas, dois filhos, uma irmã, uma tia, quatro criadas e um criado) e, por fim, o de D. Emília Adelaide Pereira Coutinho com casa na mesma rua que junto dela tem seis filhos, uma cunhada, sete criadas, quatro criados e um homem sem qualquer indicação, num total de 20 pessoas.

\footnotetext{
${ }^{95}$ Como, por exemplo, o conhecido Olímpio Nicolau Rui Fernandes, tipógrafo de profissão, que chegou a ser administrador da Imprensa da Universidade e escrivão da Misericórdia por um breve período, que vive em 1875 na Rua da Ilha com duas criadas.
} 
Assim fica bem claro que os agregados muito grandes são de gente de condição social elevada ${ }^{96}$ e essa grande dimensão deve-se não só aos muitos filhos, pois nestas famílias mais que nas outras as gravidezes se sucedem e a infância se prolonga, mas também e principalmente à maior complexidade das mesmas. Debaixo do seu tecto medra uma vasta parentela, mormente irmãs e tias, fruto das estratégias de defesa de património que conduzem ao celibato para evitar a fragmentação por via do dote, mas também muita criadagem, amas, escudeiros e escravos, clientelas e protegidos de diversa natureza, pois faz parte do corpo ideológico destes estratos sociais a obrigação de proteger os seus. E, por fim, em casas de gente temente a Deus e que sabe o valor social da religião, se mantêm padres capelães, como acontece na casa de Miguel Osório Cabral de Castro, na de Roberto Guilherme Woodhouse Barreto Lencastre e sua mulher, viscondessa de Balsemão ${ }^{97}$, ambas na Couraça de Lisboa, e na de D. Rita de Albuquerque, da Quinta das Varandas, todas em 1875. E, também se albergam, depois da extinção das Ordens Religiosas, frades egressos ao desamparo, como alberga em 1851 Joaquim José Correia, negociante morador na Rua do Corvo, o egresso D. José da Conceição, pois nem todos eles teriam a capacidade de viver por si como mostra ter o presbítero João António Pinheiro de Magalhães, egresso franciscano, que reside nessa data com uma criada na Rua de Baixo $^{98}$.

E em 1875, em casa do citado Miguel Osório Cabral de Castro, encontra-se uma mestra, provavelmente contratada para ensinar as três sobrinhas que juntamente com a mãe e duas irmãs com ele vivem, circunstância que

${ }^{96} \mathrm{O}$ que vem corroborar os resultados já obtidos para outros espaços da zona centro do país. Ver MOTA, Guilhermina - Estruturas familiares no mundo rural..., cit., p. 50-59 e MOTA, Guilhermina - Notas para o estudo da família em Penela ..., cit., p. 291-298.

${ }^{97}$ De seu nome D. Isabel Emília de Sousa Vahia de Madureira, filha dos $1 .^{\text {os }}$ Viscondes de São João da Pesqueira, tinha-se casado uma primeira vez, em 27 de Novembro de 1839, com Luís José Alexandre Pinto de Sousa Coutinho Alvo Godinho Brandão Pereira Perestrelo, 3. ${ }^{\circ}$ Visconde de Balsemão. Ao voltar a casar-se, em 3 de Junho de 1853, com o referido Roberto Guilherme Woodhouse Barreto Lencastre, perdeu o direito ao título, embora o pároco mantenha essa forma de tratamento no rol. Ver Nobreza de Portugal ... Coord. ZÚQUETE, Afonso Eduardo Martins. Lisboa: Editorial Enciclopédia, 1960, vol. II, p. 369.

${ }^{98}$ Em 1839 ficara habilitado a receber uma prestação mensal de $7 \$ 200$ a pagar pelo Estado. Arquivo da Universidade de Coimbra - Relação dos Egressos das extintas Ordens Religiosas, fl. 2v. 
demonstra que a opção de ministrar a educação em casa existia nas classes mais elevadas.

Bem se entende que só gente de dinheiro e condição pode ter casas espaçosas para poder acomodar tanta gente, e casas com crescente especialização funcional através da multiplicação de aposentos destinados a fins próprios, para resguardo da necessária privacidade e intimidade que cada vez mais se preza a partir do século XVII. Os outros tinham de contentar-se com casas pequenas e modestas, com pouca diferenciação de espaços, em alguns casos com uma boa parte ocupada até pelos instrumentos de trabalho, como acontece com os artífices.

Tal como hoje, os agregados nucleares, ou seja, os constituídos só por casais ou por pais e filhos estão sempre em maioria. Em Almedina são 57.5\%, em São Pedro 55.6\% e em Santa Cruz 51.5\% ${ }^{99}$, com uma média de filhos por agregado de 0.9, 1.4 e 1.2 respectivamente; no caso de São Bartolomeu esse valor baixa para 0.7 , mas é de lembrar que não arrola os menores de sete $\operatorname{anos}^{100}$. Mas se o indicador utilizado for o número médio de filhos por unidade conjugal já os valores são mais elevados, orçando os 2.2 em todas as freguesias - o que não anda longe dos já encontrados para freguesias rurais da zona centro em $1801^{101}$-, menos na de São Bartolomeu que tem 1.7 apenas. No entanto, a manutenção dos filhos em casa parece ter baixado ao longo do tempo. Ao comparar as idades dos filhos percebese que a forte diminuição no seu número se dá a partir dos 25 anos em São Bartolomeu - o que coincide com o momento em que atingem a maioridade -, ao passo que se dá aos 15 em Santa $\mathrm{Cruz}^{102}$. Aqui, os filhos seguirão o seu

${ }^{99} \mathrm{Na}$ freguesia da Sé Velha tais cálculos não se tornam válidos, pelas distorções que a lista apresenta.

${ }^{100}$ Comparem-se estes resultados com os de 0.9 apresentados por Álvaro Ferreira da Silva para Oeiras no século XVIII, também sem menores de confissão, valores que o Autor considera baixos, especialmente se considerarmos a média de 1.2 do número médio de filhos por unidade conjugal. Ver SILVA, Álvaro Ferreira da - A família em Portugal no século XVIII: posição familiar dos jovens e dinâmicas dos grupos domésticos. In La historia de la familia en la Península Ibérica: Balance regional y perspectivas. «Homenaje a Peter Laslett». Coord. Francisco García González. Cuenca: Universidad de Castilla-La Mancha, 2008, p. 379-380.

${ }^{101}$ MOTA, Guilhermina - Estruturas familiares..., cit., p. 32.

${ }^{102}$ Em São Bartolomeu, os filhos que têm entre 20 e 24 anos representam 11.7\%, ao passo que os que têm entre 25 e 29 representam 4.4\%. Em Santa Cruz, os filhos que têm entre 10 e 14 anos são $14.5 \%$, ao passo que nas classes etárias seguintes baixam significativamente: 
caminho mais cedo, não estando a saída da casa paterna relacionada com o casamento, pelo que se depreende da sua juventude. Tendo a área rural da paróquia de Santa Cruz, em proporção, mais fogos (21\%), que a área rural da de São Bartolomeu (12\%), é possível que seja a dura vida do campo a impelir os filhos a abandonar o lar paterno de forma precoce.

A existência de famílias monoparentais é considerada por muitos como fenómeno recente, inscrevendo-se em nova organização familiar surgida nas últimas décadas, fruto da multiplicação dos divórcios e do aumento da maternidade fora do casamento. A esse facto se associa até a instabilidade emocional das crianças, pela falta das adequadas referências biparentais. A verdade é que muitas crianças do passado também foram criadas com essa falta e com uma carência ainda mais dramática, porque era a morte que lhes levava os pais. Esta irrompia mais cedo no decurso da vida, deixando ficar muitos órfãos em tenra idade e em muito maior desventura, pois a sociedade mobilizava bem menos meios de protecção. Em Coimbra, nos séculos XVIII e XIX, o peso das famílias monoparentais é evidente ${ }^{103}$. Se na freguesia de Almedina apenas representam 1.3\%, são mais de 10\% em São Bartolomeu, chegando em S. Pedro e em Santa Cruz aos 14\%, na maior parte famílias chefiadas por viúvas pois as mulheres tinham sempre mais dificuldade em voltar a casar-se, sobretudo se carregadas com os filhos do falecido e sem recursos ou meios de fortuna.

No passado, é na composição dos agregados familiares que se encontram maiores diferenças em relação às famílias de hoje, desde logo pela presença de parentes, sobretudo pais ou sogros, irmãos ou sobrinhos e netos. Também na cidade de Coimbra a sua presença se faz sentir. A representatividade dos parentes no conjunto dos efectivos populacionais oscila entre os $6 \%$ da freguesia de Almedina e os $9 \%$ da de São Pedro. Não é muito elevada, se atentarmos que, na de Santa Cruz em 1851, a proporção de 7\% é bem semelhante ao que acontece no Porto em 1847 na freguesia de Cedofeita

dos 15 aos 19 são $8.6 \%$, dos 20 aos 24 são $8.8 \%$, e dos 25 aos 29 são $4.6 \%$. As listas das outras freguesias não indicam as idades com a frequência necessária para ter representação estatística.

${ }^{103}$ Considerei apenas os agregados familiares onde vive um pai ou uma mãe sós, com um ou vários filhos solteiros e não aqueles casos em que os pais e filhos constituem unidades familiares insertas em agregados chefiados por outrem. 
(6.6\%), e mesmo nas cidades de York e de Preston em 1851 (com 6.4\% e $7.4 \%$ respectivamente) $)^{104}$.

A existência de parentes nas casas pode ter significados diversos. No caso das mães ou sogras, viúvas e idosas, pode significar protecção dada pelos filhos quando elas envelhecem, mas cuja colaboração nas tarefas domésticas e na criação dos netos não deixava de ser preciosa. São sempre em número muito mais significativo (78\%) que os pais ou sogros, são mesmo nove vezes mais na paróquia de $\mathrm{S}$. Bartolomeu, e a totalidade na de Almedina. Isso acontece em parte porque lhes sobreviviam devido à maior longevidade feminina, em parte porque os homens com mais dificuldade se privavam da autoridade da chefia dos agregados, ao passo que as mulheres mais facilmente se moldavam às necessidades indo viver com os filhos. Só no caso das famílias de condição social elevada, as mulheres permanecem à frente de suas casas. No todo, os pais, mães ou sogros a residir com os filhos são pouco numerosos - vão dos três de Almedina aos dezanove de Santa Cruz, ou seja, 1\% dos habitantes -, o que demonstra o forte pendor nuclear das famílias em Coimbra que é sublinhado pelo carácter residual da presença de genros e de noras - aqui a presença masculina bem mais forte, pois os genros são 70\% -, que decrescem da Alta para a Baixa e ao longo do tempo ${ }^{105}$. Reflexo disso, o pouco relevo dos agregados múltiplos, aqueles que têm mais que um núcleo conjugal, que são $0.5 \%$ em São Bartolomeu, 1.1\% em Santa Cruz, 3.1\% em Almedina e 4\% em São Pedro, a maior percentagem aparecendo nas freguesias da Alta, o que corre em paralelo com a maior presença de genros e de noras. Estas são freguesias, como vimos no início, onde vivem pessoas de condição social elevada e assim não admira que na de Almedina os agregados múltiplos pertençam a um lente, a um doutor, a uma dona, a um bacharel, a um solicitador e a um artífice (um sirgueiro). De ressaltar, no entanto, que na freguesia de São Pedro, dos 21 agregados múltiplos, 16 são na área rura1 ${ }^{106}$, o que significa que os lavradores também

\footnotetext{
${ }^{104}$ PEREIRA, Gaspar Martins - Famílias portuenses..., cit., p. 106.

${ }^{105}$ Há quatro genros e três noras na freguesia de Almedina; treze e seis na de São Pedro; seis genros e três noras em São Bartolomeu e apenas cinco genros na de Santa Cruz.

${ }^{106}$ Nas povoações de Bemposta, Vale de Canas, Carvalhosas, Zorro, Casal da Misarela e Misarela.
} 
desenvolvem estratégias de organização familiar com vista à defesa do património e por isso os seus filhos casam-se e ficam na casa paterna, tal como ficam num quarto dos agregados de lavradores na de Santa Cruz.

Mas, em geral, os filhos depois de se casarem não continuam em casa dos pais, pois fundam o seu próprio lar, e por isso a presença de três ou mais gerações nas casas é diminuta, rondando os 3 ou 4\%. Reverso da medalha, muitas pessoas na velhice encontram-se a viver sozinhas. Não devemos entender, contudo, os grupos domésticos como unidades inteiramente autónomas. As relações familiares mantinham-se para lá das barreiras corresidenciais, podendo haver formas várias de interacção, de auxílio e de apoio, sobretudo a idosos e doentes, como a confecção de refeições, a prestação de cuidados de higiene e de limpeza. O viver isolado não deve ser tomado necessariamente como um sinal de abandono por parte da família. Na Europa meridional os laços familiares são, em regra, fortes, mesmo quando o modelo familiar dominante é o nuclear como acontece em Coimbra.

Quando os parentes são irmãos e cunhados, em que as mulheres representam 3/4, ou tias e primas, aqui exclusivamente mulheres, também a explicação para a sua presença pode ser diferenciada, consoante a posição social das famílias. Em casas nobres, ou nas que têm estratégias rígidas de casamento, a sua presença fica a dever-se ao celibato, à privação da reprodução biológica, sacrifício individual em nome de um bem maior, o do engrandecimento da casa e da família. Estes homens, e sobretudo estas mulheres, pertenciam inteiramente à casa onde nasciam e que nunca abandonavam, casa que primeiro era do pai, depois do irmão e por fim do sobrinho - por isso a expressão cruel do "ficar para tia". Em famílias que não têm essas preocupações porque pouco ou nada possuem, a sua presença traduz formas de rentabilizar os parcos ganhos, ou o aproveitamento de trabalho não remunerado. Em todas as famílias, a sua presença podia significar também amparo para não ficarem entregues à sua sorte, sobretudo quando eram viúvas e tinham filhos, e daí o aparecimento também de sobrinhos.

Muitos dos sobrinhos, contudo, estão em agregados de clérigos, os quais, não podendo criar famílias baseadas em laços conjugais, com frequência chamavam para junto de si familiares, principalmente irmãs ou sobrinhas, proporcionando-lhes a protecção de que muitas vezes careciam e obtendo eles companhia no dia-a-dia, assim como melhor organização doméstica. 
Em tempos idos, o recurso ao trabalho de criados era muito mais alargado do que hoje. Os criados, cerca de $16 \%$ da população, em São Pedro menos, são mais mulheres que homens, quase na relação do dobro. Se a proporção de parentes a residir nos agregados familiares da freguesia de Santa Cruz a meados do século XIX não anda longe da que ocorre na de Cedofeita e mesmo nas cidades inglesas referidas, já a proporção de criados manifesta claras diferenças, mais forte em Coimbra (16\%) que no Porto (13.7\%) e muito mais que em Inglaterra $(6.4 \%$ e $3.7 \%)$. O serviço doméstico perdura aqui na cidade, quando naquele país está já em clara regressão.

Os criados acumulam-se nas famílias mais importantes, mas mesmo gente de mais baixa condição social, como artífices, tendeiras e até vendedeiras, podiam usufruir da sua ajuda, ou na lida doméstica, ou no trabalho de lojas, tendas e mercados. Os escravos, que nunca foram muitos na cidade, são já uma raridade nestes tempos finais da escravatura: dois em São Pedro e três em São Bartolomeu, que pertencem a dois lentes, um doutor, um médico, e a uma viúva da Rua da Calçada.

Em Coimbra, ao longo do tempo analisado, as famílias mantêm a sua pequena dimensão e a nuclearidade na sua estrutura, não muito afastadas das famílias de hoje, se bem que manifestamente com mais filhos. As famílias grandes e complexas não são características da cidade no passado. Essa ideia de família, aliás, enraíza-se na experiência de vida das elites produtoras de uma ideologia familiar que, de facto, e como vimos, têm mais gente em suas casas, e não na realidade de outrora.

Onde a modernidade se impõe de forma cortante é no que toca à composição dos agregados familiares. Estes estão hoje reduzidos à expressão mais simples de casal e filhos, e estes cada vez mais únicos. A era industrial acabou com as tendas e oficinas dos velhos mestres artistas para dar lugar à impessoalidade das fábricas. Assim como no mundo do comércio há muito se preza a intimidade dos lares. E até o serviço dos criados, antes tão disseminado, se tornou uma recordação. 
